\title{
Redescription of Oropezella abdominalis Collin from Chile with description of the male and a key to the Neotropical genera of Ocydromiinae (Diptera, Hybotidae)
}

\author{
Rosaly Ale-Rocha ${ }^{1}$ \\ ${ }^{1}$ Coordenação de Pesquisas em Entomologia, Instituto Nacional de Pesquisas da Amazônia, Caixa Postal 478, 69011-970 Manaus-AM, Brazil. \\ alerocha@inpa.gov.br
}

\begin{abstract}
Redescription of Oropezella abdominalis Collin from Chile with description of the male and a key to the Neotropical genera of Ocydromiinae (Diptera, Hybotidae). Oropezella abdominalis Collin, 1933 (Diptera, Hybotidae) is redescribed and the male is described for the first time. An identification key to the Neotropical genera of Ocydromiinae is also provided.
\end{abstract}

KEYWORDS. Neotropical Region; Ocydromiini; Male; Systematics.

RESUMO. Redescrição de Oropezella abdominalis Collin do Chile com descrição do macho e chave de identificação para os gêneros neotropicais de Ocydromiinae (Diptera, Hybotidae). Oropezella abdominalis Collin, 1933 (Diptera, Hybotidae) é redescrita e o macho é descrito pela primeira vez. Uma chave de identificação para os gêneros neotropicais de Ocydromiinae é apresentada.

PALAVRAS-CHAVE. Região Neotropical; Ocydromiini; Macho; Sistemática.

The subfamily Ocydromiinae (Diptera, Hybotidae) is represented in the Neotropical region by the tribe Ocydromiini, with the genera Neotrichina Sinclair \& Cumming, Oropezella Collin, Hoplopeza Bezzi, Scelolabes Phillippi and Chvalaea Papp and Földvári (Smith 1967; Sinclair \& Cumming 2000; Papp \& Földvári 2001; Ale-Rocha 2006).

The neotropical species of Oropezella Collin include seven Brazilian species and one Chilean species (Collin 1933; Smith 1967; Ale-Rocha 2001). The Chilean species, O. abdominalis Collin, is an interesting species, sharing with the palearctic O. sphenoptera (Loew), the type species of Oropezella, some characters of the head and male terminalia, but differs in having the first flagellomere without style or arista and discal cell emitting three veins. A long first flagellomere without arista and three veins arising from discal cell are present in some New Zealand species of Oropezella (Collin 1933, Plant 1989). In this paper, $O$. abdominalis is redescribed, the female terminalia is illustrated, the male is described and illustrated for the first time and a key to genera of Ocydromiinae of the Neotropical Region is provided.

\section{MATERIALAND METHODS}

The material is deposited at the Instituto Nacional de Pesquisas da Amazônia (INPA), Manaus, Brazil; Canadian National Collection of Insect (CNC), Ottawa, Canada; California Academy of Science (CAS), San Francisco, USA; The Natural History Museum, London, England (BMNH).

Terms used for adult structures follow McAlpine (1981) except for male terminalia, which follows Cumming et al. (1995).
The male and female terminalia were removed from the abdomen, treated with hot $85 \%$ lactic acid and kept in a microvial with glycerin. The wing was illustrated after removed from the body and mounted between cover slides. Microvials and cover slides were pinned together with their associated specimens.

\section{RESULTS}

Identification key for the Neotropical genera of Ocydromiinae

1. Vein Rs short, arising near apex of cell bm ............................

Vein Rs long, arising before or in the middle of cell bm ... 3

2. Cell dm long; wing narrow and anal lobe undeveloped; hind tibia bristled and not geniculate at base; hind femur banded (Chile, Australasia) Hoplopeza Bezzi

Cell $\mathrm{dm}$ short; wing broad and anal lobe developed; hind tibia lacking bristles and generally geniculate at base; hind femur not banded (Chile, Australia)

Scelolabes Philippi

3. Three veins emitted from cell $\mathrm{dm}$ reaching wing margin; antenna inserted about middle of head (Chile) Neotrichina Sinclair \& Cumming

Two veins emitted from cell $\mathrm{dm}$ reaching wing margin, if the cell $\mathrm{dm}$ emit three veins then they do not reach the wing margin; antenna inserted above middle of head

. .4

4. Abdominal sclerites heavily sclerotized, punctate; pulvilli 
lacking; male terminalia hidden inside segment 8; arista present (Australasian, Neotropical, Oriental and Palaearctic Regions) Chvalaea Papp \& Földvári

Abdominal sclerites not heavily sclerotized; pulvilli present; male terminalia exposed; if the abdominal sclerites are heavily sclerotized then the arista lacking (Australasian, Neotropical and Palaearctic Regions) Oropezella Collin

\section{Oropezella abdominalis Collin}

(Figs. 1-10)

Oropezella abdominalis Collin, 1933:46; Smith, 1967:15 (catalogue).

Diagnosis. Thorax brown with postpronotal lobe, notopleuron, postalar callus and margin of scutellum palebrown to yellow; anepimeron, upper half of katepisternum, anterior margin and upper half of meron and laterotergite palebrown; legs pale-brown except coxae, base of femora, inferior surface of fore and mid femora yellow, apex of hind tibia and all tarsi brown; male with first to third abdominal segments paleyellow with a dorsal brown spot on tergites 2 and 3 .
Holotype female. Body: $3.8 \mathrm{~mm}$. Wing: $3.8 \mathrm{~mm}$.

Redescription. Frons brown, short, about 1/5 of length of face, as wide as long; antenna pale-brown, flagellum twice as long as scape and pedicell together (Fig.1); scape twice length of pedicel; pedicel with short marginal hairs; mouthparts palebrown, palpus oval, short and setose with one preapical dorsal setae longer than the others; post-cranium brown to black with pale brown sparse pruinosity; post-cranial setae short, thin and sparse; 1 ocelar pair short, proclinated; vertical seta indistinct.

Thorax brown with post-pronotal lobe, notopleuron, postalar callus and scutellum pale-brown to yellow; anepimeron, upper half of katepisternum, anterior margin and upper half of meron and laterotergite pale-brown; fine brown pruinose. Thoracic setae short, inconspicuous; acrostichals and dorsocentrals setae unisserial; notopleuron with 1 seta long and robust and 3-4 setae short and slender; scutellum with one apical pair long, robust, convergent and one lateral seta short and thin; one postalar setae short and thin.

Legs pale-brown except coxae, trochanters, base of femora, inferior surface of fore and mid femora yellow, apex of hind tibia and all tarsi brown. Mid tibia with 1 long anterior bristle in

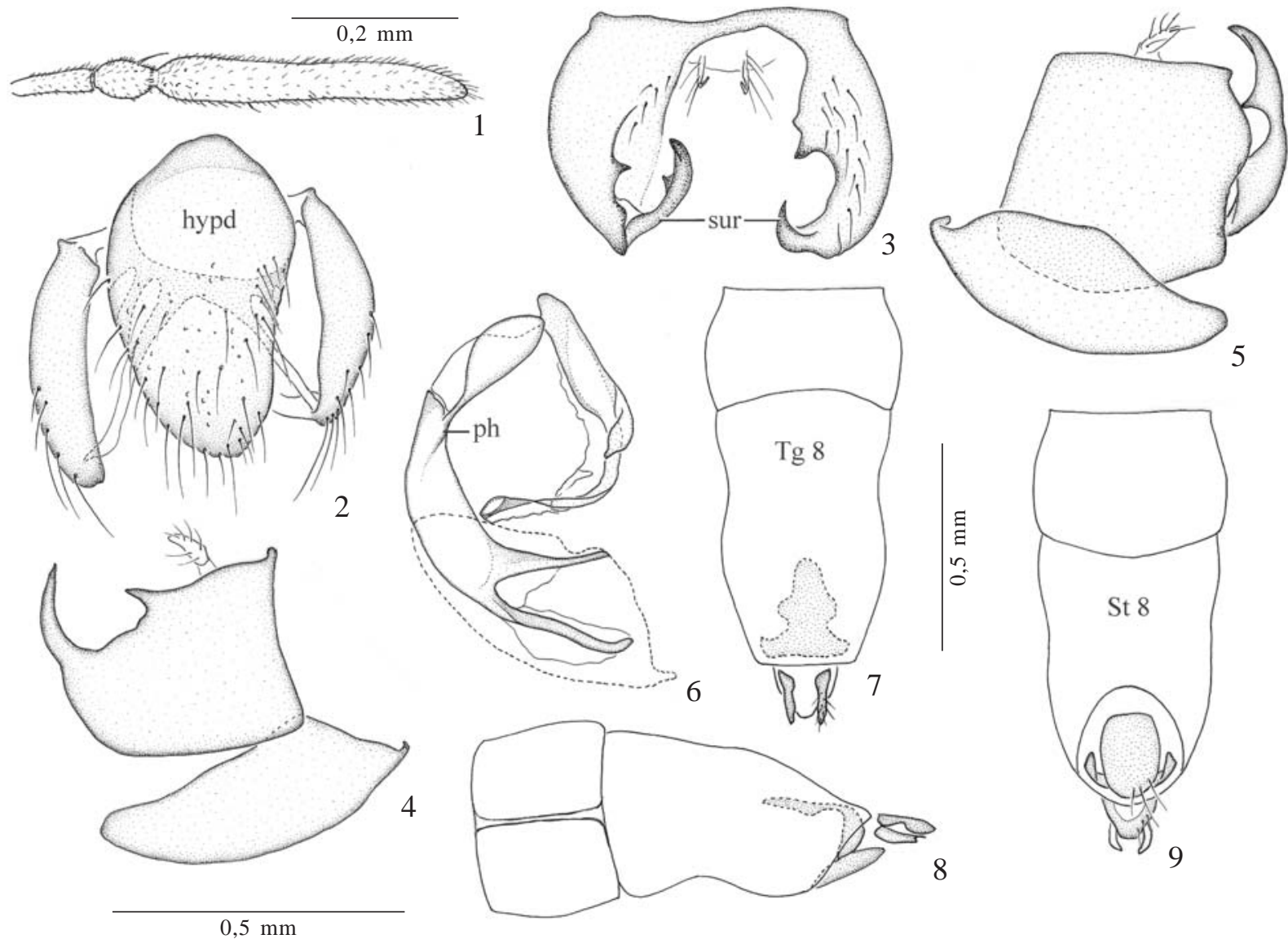

Figs. 1-9. Oropezella abdominalis. 1, antenna. 2-6, male terminalia: 2, hypandrium, ventral view; 3, epandrium, dorsal view; 4-5, epandrium and hypandrium, lateral views; 6, phallus. 7-9, female terminalia, dorsal, lateral and ventral views. Figs. 2-6, 7-9 in the same scales. Abbreviations: cerc, cercus; ep, epandrium; hypd, hypandrium; ph, phallus, St, sternite; sur, surstylus; Tg, tergite. 


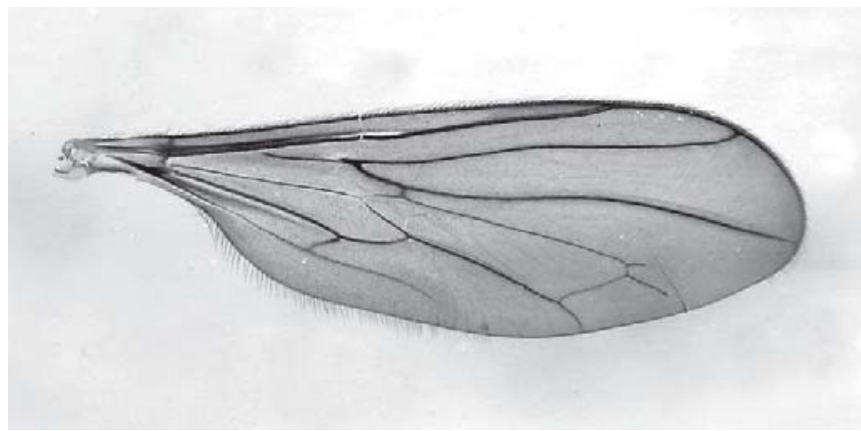

Fig. 10. Oropezella abdominalis. Wing.

the middle; 1 long posterior at basal third; 1 short dorsal and 1 long anterodorsal subbasal bristles, 1 short anterior apical and others apical setae short. Hind femur with some anteroventral elongate slender setae. Hind tibia with sparse elongate slender setae on anteroventral and posteroventral surfaces. Tarsi slender.

Wing (Fig. 10) pale-brown; pterostigma slightly brownish.

Abdome black with very fine sparse brownish pruinescence; setae pale-brown to yellow, short, slender; sclerites heavily sclerotized, segments 1-7 firmly united by a rigid membrane; spiracles obscure. Terminalia (Figs. 7-9): eighth segment tubular, tergite and sternite fused, twice the length of the preceding segment with U-shaped notch on posterodorsal margin; tergite 10 inside of the segment 8; sternite 10 visible through the notch of the posterodorsal margin of the eighth segment; cerci short.

Male. Similar to the female but bristle on legs somewhat stronger; abdomen broadened distally, pale brown except three basal segments pale-yellow with a dorsal brown spot on tergites 2 and 3, distal margin of segments with elongate setae. Terminalia: epandrium (Figs. 3-5) deep cleft dorsally, epandrial lamellae united dorsally by a narrow area; only left surstyli articulated; hypandrium (Fig. 2) broad medially and narrowed distally, apex rounded; dorsal bridge well sclerotized, complete. Phallus (Fig. 6) robust, distiphallus long, robust at basal half and slender and weakly sclerotized on the remaining.

Type material. Holotype female: CHILE: Llanquihue prov., F. \& M. Edwards, B.M. 1927-63, Peulla, 12-13.xii.1926 (BMNH). Paratype female: CHILE: Llanquihue prov., F. \& M. Edwards, B.M. 1927-63, Casa Pangue, 4-10.xii.1926 (BMNH).

Additional material. CHILE: Llanquihue, El Chingue MT, N. of Correntoso, vi-v. 1988, L.E. Pena, 1 male (CNC); i.1990, 1 male (CNC); vi-v.1988, 1 male (INPA); Osorno, $20 \mathrm{~km} \mathrm{E.} \mathrm{of} \mathrm{Puyehue,}$ 26.i.[19]51, Ross \& Michelbaker, 1 male (CNC); $30 \mathrm{~km}$ E. of Puyehue, 26.i.1951, Ross \& Michelbaker, 1 male (INPA); $10 \mathrm{~km} \mathrm{E.} \mathrm{of} \mathrm{Payehue,}$ 26.i.1951, Ross \& Michelbaker, 1 female (INPA).

\section{DISCUSSION}

Oropezella is represented in the Neotropical Region by seven species from Brazil and one species from Chile, $O$. abdominalis (Collin 1933, Smith 1967, Ale-Rocha 2001). O. abdominalis differs from Brazilian species and the type species of Oropezella, O. spnehoptera, in having the first flagellomere long, without style or arista, discal cell emitting three veins (a distinct stump of a third upper vein) and abdominal sclerites heavily sclerotized. The characters of antenna and discal cell are shared with the New Zealand species of Oropezella of Group A delineated by Plant (1989), and the heavily sclerotized abdomen of $O$. abdominalis is a characteristic found up to now only in Chvalaea. Those characteristics shared by $O$. abdominalis with different groups of species, within or outside of Oropezella, suggest that the limits of this genus need to be defined better.

Acknowledgments. I thank Jeffrey M. Cumming (CNC), Augusto Loureiro Henriques (INPA), Charles E. Griswold (CAS) and David Notton $(\mathrm{BMNH})$ for the loan of specimens of Ocydromiini.

\section{REFERENCES}

Ale-Rocha. R. 2001. Descrição de Oropezella pseudotetraocellata sp.n (Diptera, Empididae, Ocydromiinae). Iheringia, Série Zoologia 91: $85-88$.

Ale-Rocha, R. 2006.First description of Chvalaea Papp \& Földvári species from the Neotropical Region (Diptera, Hybotidae, Ocydromiinae). Zootaxa 1167: 17-30.

Collin, J. E. 1933. Diptera of Patagonia and South Chile. Part IV. Empididae. London. British Museum (Nat. Hist.) \& Oxford University Press, $334 \mathrm{p}$.

Cumming, J. M.; B. J. Sinclair \& D. M. Wood. 1995. Homology and phylogenetic implications of male genitalia in Diptera-Eremoneura. Entomologica Scandinavica 26: 121-152.

McAlpine, J. F. 1981. Morphology and terminology -Adults, p. 9-63. In: McAlpine, J. F.; B. V. Peterson; G. E. Shewell; H. J. Teskey; J. R. Vockeroth \& D. M. Wood. (Eds.). Manual of Nearctic Diptera. Volume 1, Ottawa, Research Branch, Agriculture Canada.

Papp, L. \& M. Földvári. 2001. A new genus and three new species of Hybotidae with new records of the hungarian Empidoidea (Diptera). Acta Zoologica Academiae Scientiarum Hungaricae 47: 349361.

Plant, A. R. 1989. A revision of the Ocydrominae (Diptera: Empidoidea: Hybotidae) of New Zealand with descriptions of new genera and species. New Zealand Journal of Zoology 16: 231241.

Sinclair, J. S. \& J. M. Cumming. 2000. Revision of the genus Apterodromya (Diptera: Empidoidea), with a redefinition of the tribe Ocydromiini. Records of the Australian Museum 52: 161186.

Smith, K. G. V. 1967. Family Empididae (Empidae, Hybotidae), p. 167. In: Papavero, N. (Ed.). A catalogue of Diptera of Americas South of the United States. Volume 39, São Paulo, Departamento de Zoologia, Secretaria de Agricultura.

Distribution: Chile.

Received 03/05/2007; accepted 06/11/2007 